\title{
PERSPECTIVE
}

\section{A Philosophical Memoir: Notes on Bhaskar, Realism and Cultural Theory ${ }^{1}$}

\section{John Roberts}

University of Wolverhampton, UK

I first read Roy Bhaskar in Radical Philosophy in 1980, when 'Scientific Explanation and Human Emancipation' appeared. ${ }^{2}$ But when Bhaskar's work cropped up in Art \& Language's writing in the early 1980s I resolved to read his A Realist Theory of Science (1975) and The Possibility of Naturalism (1979). ${ }^{3}$ I remember buying both from the excellent philosophy section of the old Compendium Books store in Camden Town. Art \& Language were (probably) the first artists and art-theorists to recognise the critical importance of Bhaskar's writing for a non-reductive account of realism in relation to art and cultural theory, given their general familiarity with debates in the philosophy of science and Anglo-American philosophy of language. W.V.O. Quine and Nelson Goodman, for instance, were part of the group's daily conversational practices as artists during this period. ${ }^{4}$ Indeed, given their familiarity with the issues of intention, intension, the causal theory of representation (ofrelations) the critique of empiricism and their general grounding in analytic philosophy and Boolean formal logic, the group were certainly well placed to develop Bhaskar's own ground-breaking critique of empiricism in the philosophy of science, and push it in a productive cultural direction. Bhaskar became a crucial mediating figure between the 'post-metaphysical' interrogative mechanics of the analytic tradition and the genealogical-materialist commitments of Marxism, a link at the time that was then a growing influence in English Marxism, which eventually mutated a few years later, unfortunately, into the less than compelling analytical Marxism. ${ }^{5}$

As was widely acknowledged during this period Bhaskar's concept of realism as an emergent category (of powers, relations and tendencies), became an underlabourer for a growing reassessment of Marx as a realist thinker, certainly the Marx of Capital, where methodologically issues of stratification, negation and constellationality were crucial. This is why politically, as much as philosophically, Bhaskar was part of a loose group of philosophers and political theorists in the UK in the 1970s who were

\footnotetext{
${ }^{1}$ Published, Journal of Critical Realism, Vol 15, No 2, 2016, pp175-186

${ }^{2}$ Bhaskar1980.

${ }^{3}$ In fact, in Art \& Language's 1982 painting, Index: 3 Wesley Place, which depicts the interior of their studio with the group at work, and their various working artistic and intellectual resources hung on walls or laid out on tables (in the spirit of Courbet's The Painter's Studio: A Real Allegory [1855]), they include, on the far right table, a copy of $A$ Realist Theory of Science.

${ }^{4}$ Of particular importance were Goodman 1968 and Quine 1951.

${ }^{5}$ Roemer, ed., 1986 (although this does contain Gerry Cohen's brilliant essay 'The Structure of Proletarian Unfreedom').
} 
addressing questions on Marx, realism and methodology, such as David-Hillel Ruben, Derek Sayer, Sean Sayers, Tim Benton, Kate Soper, Andrew Collier, Christopher Norris, Chris Arthur, Simon Clarke, and Alex Callinicos. In what ways is Marx's realism 'productivist' as opposed to 'reflectionist'? In what ways is Marx's dialectic specifically realist ${ }^{6}$ This range of work was particularly incisive at the time, given the rapid retreat in the academy and public debates from a non-positivistic Marx under the growing shift of post-Althusserianism into post-Marxism and the postmodern onslaught. Most of this early reception of Bhaskar and Marx-as-realist, was done either consciously or indirectly in response to this newly muscular reactionary context.

Certainly in my own writing, Bhaskar created a pathway to think about realism in art, as opposed to realism as art; ${ }^{7}$ and as such, a way of cutting through the conflation of realism with resemblance and its association with the conventional painterly realism that still dominated both official art history and the emerging social history of art. For what Bhaskar's stratified account of realism allowed in relation to cultural questions was a discussion of realism and truth separate from the empirical, disaligning the real in classical scientific terms, so to speak, from realism, and therefore divorcing politics in art from any simplistic adherence to the aesthetics of realism; indeed, realism, in these terms, might have little to do with what is commonly understood as 'representation' or picture-making at all. This move, of course, did not stand-alone culturally, insofar as in an important sense the notion of realism-asmethod was backed up by excellent avant-garde credentials. Roman Jakobson, for example, had published an important assessment of the 'relativism' of realism as a category in art and literature in the Soviet Union in the early 1920s, long before the state sanctification of 'socialist realism', but little of this debate and the legacy of the Society for the Study of Poetic Language (OPAYAZ), was available in the West until the mid-to-late 1970 s. $^{8}$ Similarly ${ }_{2}$ in the mid-to-late 1970s, the key German debates from the 1930s (Theodor Adorno, Walter Benjamin, Ernst Bloch, Bertolt Brecht, and György Lukács) were translated, allowing a renewed insight into Jakobson's understanding of realism as a contested category. ${ }^{9}$

There was a fruitful period of exchange ${ }_{L}$ therefore, between the newly emergent philosophical realism and this legacy of the avant-garde, following further English translations of the Russian Marxist-Formalist writers from the 1920s, and Brecht's 'counter-realist' theory. In addition, in 1980 Terry Lovell published her influential Pictures of Reality: Aesthetics, Politics and Pleasure, which used Bhaskar to generate a model of realism in cultural theory and film aesthetics, that relied on (some of) these avant-garde precedents. If realism was to be understood as an emergent category, then, in art and film it couldn't be held to derive from fixed genres, stable naturalistic relations, and narrative continuity; on the contrary, social appearances in the spirit of montage - needed to be de-naturalised, re-narrativised and resignified through a process of conceptual abstraction. But if Lovell uses Bhaskar and

\footnotetext{
${ }^{6}$ See in particular Sayer 1979.

${ }^{7}$ See Roberts 1992 and 1993.

${ }^{8}$ See Jakobson 1921.

${ }^{9}$ Adorno et al. 1978.
} 
the recently translated avant-garde theory to depose conventional accounts of realism, she made an additional move against what might be construed as being the dominant philosophical-avant-garde paradigm of the time: Althusserian antihumanism and theoretical conventionalism. In a direct sense Pictures of Reality was a 'clearing out' of the post-Althusserian post-realist consensus from seventies Screen-influenced film theory, in which a concept of constructedness in film and art is confined to the highly attenuated notion of the 'open text' - the film/artefact that reflects on its own means of production and signification. ${ }^{10}$ In contrast to this version of anti-naturalism, Lovell called for a 'post-coventionalist' constructed realism that was partly indebted to Brecht - although critical of what she saw as Brecht's residual rationalist 'cognitive realism'__ but also to Raymond Williams's notion of a 'subjunctive' realism, a realism not in the 'indicative sense of recording contemporary reality, but in the [prospective] sense of proposing a possible sequence of actions beyond it. ${ }^{11}$ In these terms, Lovell's and Williams's respective identification of realism with the construction of the popular (later to become crucial to British Marxist cultural studies, albeit without the allegiance to realism) marks out the production of the spectator/political subject as an enabling agent of collective political transformation. Lovell's intention, on this score, was clear: 'It is impossible to produce a truly revolutionary text in a discourse in which only the dominant have any facility. ${ }^{12}$

But in some sense this popular and prospective realism was stillborn, as the political conditions for such a cultural politics in and outside film culture shifted with the rise of the new right, diminution of the political force of the industrial working class, and crisis of class identity and politics as a result of a massive shift in the composition of the social base of the industrial working class globally. Indeed, who was actually to participate in, and sustain this realism as a popular counter-hegemonic project, when much of labour movement was moving in the opposite direction, and labour culture as a site of stable industrial-based identities (certainly after the 1984 miner's strike) was in decline? Also, Lovell's (and Williams's) too easy dismissal of the avantgarde as elitist compounded the problem in its re-routing of the question of realism back into anti-formalism in an unconscious re-run of the debates on film in the Soviet Union, after the populist attacks on Sergei Eisenstein's October as 'incoherent' at the 1928 Party conference on film. Lovell's notion of the popular text has clear echoes of Anatoly Lunarcharsky's defence of Vsevolod Pudvokin's 'popularnarrational revolutionary cinema' (The End of St.Petersburg) as a proto-Hollywood counter to the Russian-Futurist legacy. ${ }^{13}$

Nevertheless, the importation of a broadly anti-positivist realism into cultural theory and film theory during this period (indebted to both Bhaskar's critical realism and the new counter-realist milieu) created a renewed expectation that a rearticulated realism might offer a new politics in art that avoided the pitfalls of conventional realist aesthetics - it is just that the defence of a post-Brechtian and Williamsian

\footnotetext{
${ }^{10}$ The classic formulation is MaCabe 1974.

${ }^{11}$ Williams 1979, 218-19.

12 Lovell 1980, 87.

${ }^{13}$ See Leyda 1960, also Kepley Jr. 2003.
} 
'popular text' wasn't able carry this forward without both bathos and pathos. This is because realism, or realism-as-philosophical method rather than realism-asaesthetics, needed to reconnect with modernism and the avant-garde in all their complexity if it was to secure an openness for itself in these severely reduced circumstances. Realism and the avant-garde needed to be conjoined; not pushed apart. Indeed, by 1983 the debate on realism had once more come to seem utterly provincial - certainly in the visual arts - in an unfortunate reprise of debates from the 1930s, in which 'good faith' and earnestness in the form of the revival of realist painting was pitched against what was left of a righteous post-Althusserian politics of deconstruction that overly identified art (photography) and film with 'ideology critique'. As Terry Eagleton was to say in his review of Aesthetics and Politics in New Left Review in 1978, in some sense pre-empting the terminal crisis of the AngloAlthusserian avant-garde:

It is temptingly easy to caricature the aesthetics to which a case leads - to fantasize that films which draw your attention to the camera thereby impel you out inexorably onto the picket lines. But if that is indeed a caricature, it can hardly be said that some aspects of this case's conception of realism are anything less. For realism, in so far as it aims at the fixing of naturalized representation whose traces of production have been repressed, is by that token intrinsically reactionary...In a comical inversion of the aesthetics of Lukács, realism is now the ontological enemy. ${ }^{14}$

This is why the publication of Theodor Adorno's Aesthetic Theory in English in $1984^{15}$ was extraordinarily important for me and a number of other writers of my generation, who were committed avant-gardists, yet wanted nothing to do with post-Althusserianism and post-structuralism, and who, in turn, had no truck with conventional realism, yet remained philosophically committed to some conception of realism out of Marx that might be useful for an 'open-ended' and transformative understanding of cultural practice and artistic subjectivity. Admittedly, this was certainly a difficult juggling act, and there was nothing initially to suggest culturally that something like a conjunction of Adorno and Bhaskar's realism might bear fruit. But what Aesthetic Theory foregrounded above all else, in contrast to what might have been picked up more generally from the collection Aesthetics and Politics, was the notion that the asymmetry between the real and realism, realism-as-method and realism-as-aesthetics, might provide a politics of negation for art, in which the critique of artistic form - not just the 'critique of representation' - was productive and enabling. Moreover, Adorno's own philosophical 'realism' - his attack on voluntarism and leftist cultural piety - provided a better critical armature for a politics of the Thatcherite and Reaganite conjuncture than did a renewed cultural studies attached to 'identity politics' and a sanguine populism, whether identifiable with postmodernism or not. That is, crucially, Adorno's 'aesthetic theory' did not fall for the notion that all art had to do in order to produce a critically transformative spectator was to 'politicize' itself and enter 'living social relations'. On the contrary,

\footnotetext{
${ }^{14}$ Eagleton 1978, 24

${ }^{15}$ Adorno 1984.
} 
the politicization of art could just as easily be compatible with humanist sentiment and with the whole self-deluding machinery of substitutionist and actionist fantasies. Hence what Adorno's Aesthetic Theory opened up, for this writer at least, was a politics of culture that retained the singular force and presence of modernist negation - of distanciation and disaffirmation - but within a cultural-political framework that took no comfort or solace from modernist forms of aestheticism and 'anti-representation'. But this was an Adorno not instantly recognisable from Aesthetic Theory and from the received assumptions about Adorno as a critic of mass culture and jazz; one therefore had to perform a symptomatic reading to get the best out of Adorno's text; or rather - more affectingly - in order to stay with the spirit of the book one had to steer it away from the clichéd notion that it was the theoretical summit of a gloomy modernist elitism - still the received view of Adorno on the left in the mid-1980s. On the contrary, Aesthetic Theory is riven with interesting caesuras, glitches, aporias, and hiatuses in its account of the modern in art, that derive from Adorno's (necessarily) unresolved negative dialectical account of art's autonomy and heteronomy under monopoly capitalism. Although there is little systematic attention given to the visual arts and visual culture in the book, nevertheless, at various points, Adorno is highly sensitive to the ease with which an aestheticized concept of autonomy in modern art (of formal abstraction, nonrepresentation, 'non-communication') is able to accommodate itself to the market and academic administration, irredeemably weakening any presumed link between aesthetic transcendentalism and resistance. This means that for Adorno there is no essence of modernism to defend as a redoubt against mass cultural heteronomy, and certainly not against conventional realism. Indeed, if Adorno defends modernism in Aesthetic Theory at all, it is a modernism shot through with a disaffected and self-negating drive to escape art itself, a position inherited from the avant-garde critique of the art institution. And, two of the most interesting moments of this self-negation (amongst many), are his brief use of the figure of the philistine as a counter-cultural spectre of bourgeois aestheticism and transcendentalism, and his equally significant notion that, after Hegel and Romanticism, after conceptual art, and the crisis of modernist aestheticism, art has a working non-identitary relationship to ideation in art, that necessarily puts its canonic visual and sensible forms under jeopardy. As he says, firstly, vis-à-vis ideation: 'the widely accepted notion - a bowdlerized theorem of aesthetics ... [is] that art per se ought to be visual. It ought not. Art belongs squarely in the conceptual realm ${ }_{2}^{\prime 16}$ and, secondly, vis-à-vis the philistine:

Artlessness or philistinism is the antithesis par excellence of aesthetic behaviour. While it frequently shades into the vulgar it is different from vulgarity, representing indifference to or hatred of art where vulgarity is more like an uncouth smacking noise. Politically the ban on artlessness is as culpable as the emphasis on nobility, for it rates mental labour higher than physical labour...Art needs this ideological aspect if it is able to correct itself perpetually. ${ }^{17}$

\footnotetext{
${ }^{16}$ Adorno 1984, 461.

${ }^{17}$ Adorno 1984, 342.
} 
Although, these, two notions, are mere isolated moments in Aesthetic Theory, combined with Adorno's general critique of aestheticism, they provide vivid instances of Adorno's model of negation in relation to the exigencies of artistic form and the division of intellectual labour and artistic subjectivity. Indeed, they go to the very heart of art's intimate and conflicted place in the relations between autonomy and heteronomy, insofar as they stage autonomy in art as a social relation. In other words autonomy is produced out of art's heteronomous conditions of possibility; it is not an inherited (modernist) style or set of specific aesthetic moves.

As such, the suggestiveness of this was a spur for Dave Beech and myself in the mid1990s to attempt to do justice to Adorno's insights and to a workable theory of negation in art in our systematic encounter and theorization of the philistine as the would-be via negativa of the aesthetic. That is, despite its spectral presence in Aesthetic Theory, the philistine promised all kinds of critical opportunities for a theory of negation that could move the philosophical debate on realism and politics in art forward, in a political and cultural context, where the revival of 'aesthetics' had again frozen the complexities of the autonomy/heteronomy relation, and realism itself. In this sense the debate on the philistine was, in short, a new version of an old cultural debate - the debate on class, art and emancipation that goes all the way back to Jean-Jacques Rousseau's critique of art as bourgeois amour propre, ${ }^{18}$ and to Kant and Hegel's dialectical negation of this critique in the interests of art's universal emancipatory spirit - that Marx (and Adorno) inherited.

This is why Bhaskar's own shift to an explicit model of dialectical negation following his own 'Marxian/Leninist/Adornian' encounter with Hegel, so to speak was so crucial to our thinking at the time, for it allowed us to think the philistine relationally across the autonomy/heteronomy divide. For, contrary to some of our critics, at no point did we ever see the cultural figure of the philistine as a solution to cultural division, or as an emancipatory herald of proletarian revolution; rather, what made the philistine an interesting figure in relation to both the production and reception of art, was precisely its immanent, negating character. The philistine

is not a non-specific other, but holds a non-transferable position in cultural relations. And, in this way, it is related hierarchically to other nontransferable positions such as the aesthete and connoisseur. This is because the philistine is the outcome of the complex positions produced by the internal relations of cultural division. ${ }^{19}$

Consequently in our reading of Bhaskar's Dialectic: The Pulse of Freedom (1993), we saw an opportunity to draw out the immanent negative character of the philistine on a systematic basis, through an adaptation of Bhaskar's account of negation as real determinate absence. That is, following Bhaskar argument, the character of the

\footnotetext{
${ }^{18}$ Jean-Jacques Rousseau, Discours sur l'origine et les fondements de l'inégalité parmi les hommes. Discours sur les sciences et les arts, GF Flammarion, Paris, 1992

${ }^{19}$ Beech and Roberts 1998, 50
} 
philistine as the 'uncultured' or 'culturally excluded', is not a positive identity, amenable to 'politicization' but ${ }_{2}$ on the contrary, a shifting identity that consistently haunts the relations of bourgeois culture as the repressed or barely acknowledged determinate absence immanent to cultural division. It cannot, therefore, fulfil a transparently emancipatory role at all, because the emancipatory content it possesses is marked by its structural exclusions; that is, the 'uncultured' cannot magically become the 'otherly-cultured'. In our two essays for New Left Review, (1996-8), then, the philistine as real determinate absence becomes a way of reintroducing a realist asymmetry into the debate on art and politics and emancipation - and not, as was occasionally assumed by our critics, an anti-aesthetic stand-in for the Bakhtinian carnivalesque or anti-Kantian voluptuous body. That is, the philistine functions as the self-negating haunting of the aesthetic, rather than its antipode. Thus, we might say, in Bhaskar's terms, that although the philistine has no positive identity as a negation of trained aesthetic judgement and critical cultural competence, given its shifting position internal to the relations of cultural division, its absenting of bourgeois cultural power is a condition of bourgeois culture's intelligibility as a class formation; that is, the philistine's non-deferential absenting of such competences exposes such competences to class scrutiny. This is why Bhaskar was keen to talk in Dialectic about absence as real absence. ${ }^{20}$

Something of this ambiguity about the function of the philistine and what our notion of the philistine was actually doing - was it an anti-aesthetic or 'hedonistic' inversion of the bourgeois aesthete or a figural 'haunting' of bourgeois culture? - was reflected in Gary MacLennan's response to our writing in Journal of Critical Realism in $1998 .{ }^{21}$ If MacLennan is supportive of what the philistine promises as real determinate absence in relation to exposing the class function of culture, he is less persuaded by what this actually means in terms of 'philistine modes of attention' and philistine forms of agency on the ground. And he would be right. There is little critical leverage or self-transformative agency to be won from the supine pleasures of mass culture, or from rejecting 'high culture' per se. But, the philistine was never designed to elevate such fallen pleasures, despite our initial indulgence in a kind of rebarbative proletarianization of the pleasures of the popular, which might be described as the Proletkult phase of our theory of the philistine. Rather, more broadly and more convincingly, the philistine was a way of thinking class subjection in culture without opting for the two usual 'improving' solutions to its usual rebarbativeness: firstly, the outright rejection of the philistine as a manifestation of false consciousness, and as such, the advocacy of the transformative power of 'good works' (as in the edifying edicts of the humanism, left or right); or, secondly - the cultural studies option - the assimilation of the philistine into an affirmative account of popular pleasures and pastimes as forming micro-communities of resistance, in which hairstyles have equal billing with avant-garde films. Neither option is successful in resolving the problem of the philistine, precisely because each positivizes what it assumes to be its failings or strengths, missing the way in which, as a real determinate absence, the philistine can never be equal to any negative or

\footnotetext{
${ }^{20}$ Bhaskar 1993, 238-41.

${ }^{21}$ MacLennan 1998.
} 
positive identity attributed to it. As such what our non-identitary definition was designed to accomplish, then, was something altogether more affecting and purposeful: the return of 'political reason' to those ostensibly outside of culture who resist the overtures of bourgeois culture. Humanist and aestheticist correctives and cultural studies subaltern advocacy fail to do this given their respective diminishment of the philistine as a self-reasoning and autonomous concept-user, albeit one whose range of options and transformative possibilities are severely constrained by this assumed autonomy. But this is precisely the point: to defend the philistine is to defend the reason of non-compliance, not an acceptance of the 'reason' of the idiot savant or ignorant. In other words, in recognizing the fractured and torn subjectivity of the philistine as that which ontologically cannot be assimilated to the humanism of aesthetic discourse, aesthetic discourse's claims to universal inclusion are rendered frangible.

Why embark on such a critical trajectory though? What is to be gained in defending this negative space within aesthetic discourse, this relation of non-relation? Well, in the 1980s and 1990s, quite a lot, when the debate on culture and art was overrun by postmodernism and post-Marxism and claims to realism-as-method-certainly in art - were considered, as such, outré and almost redundant. To offer up the philistine, therefore, as an anti-positivistic disclaimer of the current aesthetic and pluralist settlement - was deliberately provocative, particularly given its earlier twilight life in Adorno, who was then, in the US and Europe, undergoing an extraordinary 'aestheticist' reinvention as part of the new Weberian critical theory and poststructuralist reception of Adorno-as-troubled-aesthete. The New Aestheticists who entered the debate, found this invitation to the philistine the most uncomfortable of all: 'this was not the Adorno we signed up to in our fight against postmodernism.' To use the philistine, against postmodernism, against post-Marxism, against conventional realism, and against (and with) Adorno was undoubtedly touched by a kind of Marxist hubris. But this is why Bhaskar was so crucial to this move: for the realism at stake in the debate on art and culture was negatively 'expressive' (in the Hegelian sense) rather than 'reflectionist' (in the Kantian sense); that is, whatever self-conscious philistine modes of attention might be employed by artists and writers, the discussion was subject overall to the ontological condition of the philistine as a real determinate absence and, therefore, to the wider need for the absenting of this absence as a primary condition of universal emancipation. The discussion on the philistine was determined in the last instance, consequently, not by its contribution to the postmodern/modernist debate on low culture and high culture, or even the modern and the everyday, but on fundamental questions of autonomy, subjectivity and freedom. Indeed, the core philosophical concerns of the discussion were essentially those of power and self-determination: who, and what speaks, when the philistine speaks, or fails to speak? What interests does the aesthete speak to, when the philistine speaks? And, consequently, what happens to the interests of both philistine and aesthete as a result?

What is properly realist about this intervention, then, certainly for myself, was it that was a first move in a return to the debate on art and culture, to the relations between negation, the subject and the capitalist totality: something, that Bhaskar 
and Adorno share. And this is why the absenting figure of the philistine was a way of exposing the increasingly harmonious and assimilationist criteria of both postmodernism and the 'return to aesthetics', in either its modernist or conventionalist realist guises. For it provided a rent, or disaffirmative gap, through which the fictiveness of the totality of cultural relations might be exposed. This was borne out in practical terms by the double crisis of the return to aesthetics and postmodernism in the mid-to-late 1990s in the widespread 'turn to the social' in art globally, as finance capital begins to destroy its own liberal cultural base, through the marketization of all values, realising a huge amount of dissensual and critical energy that could not be contained by the old formal allegiances of the art market and art institution. Thus postmodernism may have won the hegemonic battle in the 1980s and 1990s when popular culture looked the more progressive bet for art against a deracinated high culture $_{2}$ but $_{L}$ as financial capital began to weaken the social interests of 'capital in general' and destroy the living conditions of most artists and state support, at the same time rendering art even more subordinate to commerce and the spectacle, it was unable to secure the assent of a sizeable new generation of artists and intellectuals. Emerging from this period of increasing constraint, indifferent to both market and institution, these artists began to relink the socially transformative capacities of art to a totalizing critique of capitalism. Relational and post-relational aesthetics, tactical media, participatory art, and the new forms of communal practice constitutive of the new network culture, were all central to this, as was the move, more generally, to an intellectual gift economy. The point was not that this work represented an extensive left turn in art, or had radicalized a new generation, but that technically and subjectively it opened up art to modes of doing and being not subject to the dolours of object production for exchange, and in this it made loose alliance with various 'uncultured' friends of the philistine: the amateur, the non-professional artist, the 'non-artist artist', the technician and activist. And Bhaskar, at least, for myself, in the mid-1990s, was important philosophically in grasping the avant-garde dynamic of this, insofar as Dialectic provided a language of negation without 'endism' and closed totalities. In the spirit of this anti-historicism, in 1998 Dave Beech interviewed the artist Keith Tyson, the future Turner Prize Winner (2002):

DB: Roy Bhaskar, the British philosopher, has argued that our thinking about reality has to begin with 'non-identity' and end with 'open unfinished totality'. Most philosophical mistakes, he says, 'derive from taking an insufficiently non-anthropocentric, differentiated, stratified, dynamic, holistic or practical view of things'. Don't a lot of ideas about art make these mistakes? I mean, the idea that art is expressive, or art is visual, or art is whatever an artist says it is, or art is a commodity - aren't these daft simplifications of art? And if they are, don't we have to think about making art in ways that take account of this complexity?

KT: I haven't read him yet. But that sounds like a pretty accurate description of what I was trying to do with the Artmachine. Which was to deanthropocentrise the notion of how art is. And also to make something that 
embraced complexity instead of trying to simplify it. I just cannot believe that any one descriptive or philosophical or political model is complete. ${ }^{22}$

Yet, if this clearly instances what dialectical critical realism might provide for an_antihistoricist, socially stratified and intra-relational account of contemporary art and cultural production, Bhaskar himself, unfortunately showed little interest in exploring these connections. Disappointingly, the cultural ramifications of dialectical critical realism, by the late 1990s, were swallowed up by Bhaskar's move to a spiritualized non-dualist 'creativity', which as a model of emancipation lost all traction with the vicissitudes of class subjectivity and the symbolic, the conjuncturally specific and praxiological agency. The overriding feeling was a kind of retreat to a Rousseauian account of art as amour propre; creativity was not reducible to the professional discourse of art and cultural production, and therefore lay more broadly outside of the cognitive and discursive altogether. Of course, there is no reason why Bhaskar should use dialectical critical realism to reflect on the artistic legacy of realism, modernism and the avant-garde; there was never any indication that he saw this as part of his philosophical project. Yet the valorization of a nondiscursive creativity seemed like an anti-modernist attack on the modern philosopher as an advocate for the emancipatory (non-identitary) role of art, and on the Hegelian view of the development of art as an increase in reflexive consciousness and, as such, perilously close to pushing the cultural debate into creativity-as-self-enchantment and autopoietic intuitivism. 'Thinking can never get us to action. At some point we just have to stop thinking (about), and just do; and that is spontaneous, intuitive. ${ }^{\prime 23}$ I say perilously close, because Bhaskar does admittedly say elsewhere that creativity is not 'ontologically non-immanent. ${ }^{24}$ Nevertheless, this vacillation inflates human sentience (consciousness) at the expense of human sapience (concept formation). ${ }^{25} \mathrm{And}_{2}$ crucially, as regards the political outcomes of (underused) human sapience this is not what I see was at stake in the notion of real determinate absence in cultural theory: namely bringing creativity into productive and egalitarian alignment with concept-use as part of the 'general intellect', in Marx's sense. Under the strictures of Bhaskar's metaReality, creativity becomes merely the underdetermined realm of sentient 'all inclusiveness'. In other words, to what extent is Bhaskar's critique of discursiveness liberatory?

These criticisms are certainly worth exploring another time, as part of a larger debate about creativity and emancipation, art and concept-use. But here it suffices to ask: where is dialectical critical realism best used and situated in cultural theory today? ${ }^{26}$ What useful dialectical philosophical materials might continue to be employed from Dialectic, as a means of sustaining the transformative and emancipatory link between negation in cultural theory and art and sapience? As

\footnotetext{
${ }^{22}$ Beech 1998, 18.

${ }^{23}$ Bhaskar [2002] 2012, 145. I'm sure Bhaskar had no cultural memory of this, but the quote sounds like a conservative homily from a 1960 s modernist painting tutor, intent on releasing the 'inner creativity' of his students.

${ }^{24}$ Bhaskar [2002] 2012, 134

${ }^{25}$ For a defence of the Hegelian legacy of human sapience, see Brandom 2000.

${ }^{26}$ See e.g. Verstegen 2013.
} 
such: in what ways is realism-as-method and the legacy of realism as representation (of the avant-garde and realism) mutually engaged ${ }^{27}$ Indeed, Dialectic has barely been broached as a theoretical resource on cultural questions; and yet its vividness and productive complexity was what made it such an extraordinary intervention into the 'complacencies of the age' in the early 1990s. In its range and ambition it singularly demolished the de-totalizing, de-stratifying and anthropocentric tendencies of the postmodern and retro-positivistic ascendancy. In this sense I owe it a great deal.

\section{Refererences}

Adorno, Theodor W. 1984. Aesthetic Theory, trans. C. Lenhardt, eds Gretel Adorno and Rolf Tiedemann. London: Routledge \& Kegan Paul.

Adorno, Theodor W., Benjamin, Walter, Bloch, Ernst, Brecht, Bertolt, Lukács, György. 1978. Aesthetics and Politics, with an afterword by Fredric Jameson. London: New Left Books.

Art \& Language (Baldwin, Michael and Ramsden, Mel). 1982. Index: The Studio at 3 Wesley Place. http://www.tate.org.uk/art/artworks/art-language-michaelbaldwin-index-the-studio-at-3-wesley-place-t03804

Beech, Dave. 1998. 'Another Tyson Ear Bending'. Everything 2(3): 18-21

Beech, Dave and Roberts, John. 'Spectres of the Aesthetic'. New Left Review 218: 102-27

Beech, Dave and Roberts, John. 1998. 'Tolerating Impurities: An Ontology, Genealogy and Defence of Philistinism'. New Left Review 227: 45-71.

Bernstein, J. M. 'Against Voluptuous Bodies: Of Satiation Without Happiness', in The Philistine Controversy, eds Dave Beech and John Roberts, 103-124. London Verso.

Bhaskar, Roy. 1980. 'Scientific Explanation and Human Emancipation'. Radical Philosophy 26: 16-28.

Bhaskar, Roy. 1993. Dialectic: The Pulse of Freedom. London: Verso.

Bhaskar, Roy. [2002] 2012. The Philosophy of MetaReality: Creativity, Love and Freedom. London: Routledge.

Bowie, Andrew. 2002.'Confessions of a 'New Aesthete': A Response to the 'New Philistines', in The Philistine Controversy, eds Dave Beech and John Roberts, 73102. London. Verso.

Brandom, Robert B. 2000. Articulating Reasons: An Introduction to Inferentialism. Cambridge MA: Harvard University Press.

Eagleton, Terry. 1978. 'Aesthetics and Politics'. New Left Review 107: 21-34.

Goodman, Nelson. 1968. Languages of Art: An Approach to a Theory of Symbols. Indianapolis: Hackett.

Jakobson, Roman. [1921] 1978. 'On Realism in Art', in Readings in Russian Poetics: Formalist and Structuralist Views, eds Ladislav Matejka and Krystyna Pomorska, 38-47. Ann Arbour, MI: University of Michigan Press.

Kepley, Vance Jr. 2003. The End of St. Petersburg. London: I.B. Taurus.

${ }^{27}$ See Roberts 2015, 86-91 
Leyda, Jay. 1960. Kino: A History of the Russian and Soviet Film. London: George Allen \& Unwin.

Lovell, Terry. 1980. Pictures of Reality: Aesthetics, Politics and Pleasure. British Film Institute: London.

MaCabe, Colin. 1974. 'Realism and the Cinema: Notes on Some Brechtian Theses'. Screen 15(2): 7-27.

MacLennan, Gary. 1998. 'Aesthetics and the Dialectic of Desire: Comment on Beech and Roberts'. Journal of Critical Realism 5(2): 19-22.

Quine, W.V.O. 1951. 'Two Dogmas of Empiricism'. The Philosophical Review 60(1): 20-43.

Roberts, John. 1992. 'Approaches to Realism', Selected Errors: Writing on Art and Politics, 1981-1990, 195-213. London: Pluto.

Roberts, John, ed., 1993. 'Introduction', Art Has No History!: the Making and Unmaking of Modern Art, 1-36. London: Verso.

Roberts, John. 2015. 'Aporetischer Realismus: Alter-Realismus, Als Philosophisches Konzept Und Künstlerischer Horizont', Lettre International 109: 86-91

Roemer, John, ed. 1986. Analytical Marxism. Cambridge: Cambridge University Press.

Rousseau, Jean-Jacques. 1992. Discours sur l'origine et les fondements de l'inégalité parmi les hommes. Discours sur les sciences et les arts. Paris: G.F. Flammarion.

Sayer, Derek. 1979. Marx's Method: Ideology, Critique and Science in Capital, Harvester Press, Brighton.

Verstegen, Ian. 2013. A Realist Theory of Art History. London: Routledge.

Williams, Raymond. 1979. Politics and Letters: Interviews with New Left Review. London: New Left Books.

\section{Notes on contributor}

John Roberts is Professor of Art and Aesthetics at the University of Wolverhampton, Faculty of Arts. He is the author of a number of books, including The Philistine Controversy (with Dave Beech) (Verso, 2002), The Intangibilities of Form: Skill and Deskilling in Art After the Readymade (Verso, 2007), The Necessity of Errors (Verso, 2011), Photography and Its Violations (Columbia University Press, 2014) and Revolutionary Time and the Avant-Garde (Verso, 2015). He has also contributed to various journals, including Historical Materialism, New Left Review, Radical Philosophy, Third Text, and New Literary History. His Thoughts on an Index Not Freely Given is to be published by Zero Books in 2016.

Correspondence to: jorob128@aol.com 
